\title{
Prisons, Pipelines and Pedagogy: Diary of the Birth of a Behind-Bars College Program
}

\author{
BAZ DREISINGER \\ with Krystlelynn Caraballo, Marcus Chandler, Craig Coston, Rowland Davis, \\ Patrick Gallimore, Lenecia Lewis-Kirkwood, Devon Simmons, Theron Smith, Robert Taitt, \\ Matthew Wilson and Lamumba Woods \\ John Jay College of Criminal Justice, City University of New York, USA
}

It is the obligation of our Nation to provide and permit and assist every child born in these borders to receive all the education that he can take. -President Johnson, Higher Education Act of 1965

A Black man in his thirties is twice as likely to experience prison as to earn a college degree. -Western, Schiraldi \& Ziedenberg

\section{August 10, 2011}

Last-minute teaching crisis of a peculiar variety: What to do about the slice of metal in our textbook? Spiral binders are fine in college, but not in prison. My college is in a prison-where books can be, literally, weapons.

I sit with a friend and unbound all of the textbooks. I put rubber bands around each, and all semester long my incarcerated students refer to the John Jay College Writing Handbook-source of many a grammatical woe-as, simply, "the spineless book."

Crisis averted. More follow, though, well before the first day of class and the official launch of John Jay College of Criminal Justice's Prison-to-College Pipeline program (P2CP). Would the Deputy Superintendent really read The Color of Water in time to approve it for use on my syllabus? Without a Xerox machine or computer, and with plenty of forthcoming essay drafts, would I end up producing a classroom of Bartlebys, writing and rewriting by labor of hand? Would phonein office hours from the prison counselor's office suffice?

I saw the flyer up telling us-incarcerated menthat we could sign up for college. I looked at it and was like, "Nah. Not right now. I still got time." But it kept calling me. I saw it everyday, and I kept reading it. So I decided to go to the meeting and hear how the program was run. I got an interview. And the rest is history. -Robert Taitt, inside student

In April of 2011, I went to my first parole board, and I was denied release, and ordered held for 24 months. About one month later flyers were posted up in the dorms offering John Jay college courses. At that time two things went through my mind. The first thing was that I should take this time to do something beneficial with my life. And the second thing, slight doubt within myself. I did not think that I was going to get accepted, or even pass the test for that matter. Yet I still felt that it could not hurt to try. Marcus Chandler, inside student

After being denied parole for the fourth time, I guess what could be considered my life's work came to a screeching halt. Once again, the ex-factor had reared its ugly head. Frustrated with my inability to pursue life beyond captivity, I made a pact with my self to pursue tangible goals, despite my obstacles and setbacks. My options were limited. For once in my life, things found a way of working $t$ themselves out. I signed up for the Prison-toCollege Pipeline, posted one week after the "exfactor" occurred. -Lamumba Woods, inside student

\section{August 14, 2011}

It's a sweltering day; Marcus wears it all over. He and his Timbs stride with grave purpose to our interview desk, wiping the sweat off his creased brow. He's come right from work - gardening - and he strikes me, simply, as a hard-working dad who carries the weight of family on sturdy shoulders. He wants to go to college because, tautologically, it will make him a college student: an identity label far preferable to the one he wears everyday, inside. His dream dinner companion: Martin Luther King.

On the day that I was called for my John Jay interview, I was cutting grass for approximately three hours in 90-degree weather. When I came to the interview, I had on sweaty, grass-stained clothes. When the interview was being conducted, I was out of breath and tired but still as patient and humble as I could be. While going through the process of answering questions, the experience was exhilarating, mainly because this was a challenge that I doubted myself about and avoided like the plague. And now 
here I was, face to face with this wonderful opportu nity. After being denied at the parole board, John Jay gave me something to look forward to, inside and out of prison. -Marcus Chandler, inside student Onto the next one. And the next one, assembly-line style. Some 35 men interviewed, all day long, for 14 slots. The refrains are many. I want to do college because my daughter is starting school, too, and we made a pact. I couldn't really read or write before I got here but now I'm going to be a college student. I want more than a job-I want a career. I want anything that's more than this. I just want to be a college student. Hours in, I become eager to eschew what I dub "soapbox syndrome": after years of lockup, living inside the vacuum of a world that is prison, one doesn't dialogue - one lectures. Talking at people instead of with them: a kind of armed communication that jives with incarceration.

Robert plans to open a sports lounge and study business management; he wants to read The Autobiography of Malcolm $X$ but is afraid to do so while in prison because it'll awaken thoughts he isn't equipped to deal with in here. Rowland also mentions business management, then drops references to Plato and Michelle Alexander's The New Jim Crow, a new book that's already gospel to the men inside. Theron is interested in the sociology of religion; he applied and was accepted to John Jay College 24 years ago, but then life took an unexpected turn southward-er, in the context of New York State, northward. Tony hopes to work with troubled youth, setting an example for them. His dream dinner companion? President Obama. "Reticent, thoughtful," I write in my increasingly nonsensical admissions notes. How much, after all, can be gauged from one essay and a 10-minute interview? Admissions can be arbitrary.

After being in prison for over 17 years and sitting in the presence of interviewees, I did not feel like an offender. I felt like I was participating in a new opportunity at life without being judged by my past. The piercing glance of Professor Dreisinger made me feel like a shy preschooler. My shyness wasn't the result of my natural mild character alone, but also how humbled I was due to the level of respect she addressed me with. -Craig Coston, inside student

I of course was nervous...but to be able to sit and talk academics and life in general with these two individuals and not what society labels me, made all the difference in the world. -Theron Smith, inside student

Like all of the applicants, I wanted to be accepted; however, to be considered showed me that I am qualified to be a college student regardless of my circumstances, and since has left me with a feeling of self-worth. Honestly the events leading up to the interview were more nerve-wracking for me because of the waiting process. Prior to the CUNY entrance exam, I hadn't taken a standardized test since ac- quiring my GED [high-school equivalency diploma] back in 2000. As a result, I was feeling a little insecure about myself academically. However, my competitiveness would not allow me to back down from this challenge. It was actually while in the midst of taking the CUNY entrance exam that I had an epiph any. I asked myself, "what do you have to lose?" Then I said to myself, "regardless of the outcome, I won't let passing or failing this test define me." After that moment of clarity, I stopped worrying about my penmanship, the perfect punctuation and grammar, and just did the best I could. I had been waiting over 12 years to be able to attain some form of higher education, yet I didn't let that prohibit me from continuously educating myself in the past-and I couldn't let that change.

On the day of the interview, I was undecided as to how I would get dressed. I didn't want to be viewed as a prisoner, but rather as a potential student. That's when I made the decision to throw on a collared shirt instead of my State-issued greens. When I entered the room Professor Dreisinger and the other professor had these big vibrant smiles, which calmed my nerves. Then Professor Dreisinger caught me off guard by calling me "Mr. Salutatorian." I remembered I had mentioned that accomplishment in my letter, which was right on her desk. After the interview she thanked me for my time and apologized for having me wait so long. I told her she didn't have to apologize because I had been waiting for this opportunity for over 12 years. Once I left the room my intuition told me that I'd see this woman again in the near future. -Devon Simmons, inside student

\section{August 21, 2011}

Bartlebys be gone: no computers, but thanks to a lastminute donation we have typewriters for the men to patter-patter away on. Yes, typewriters - complete with old-school ribbons. They had to be ordered from a special prison supply company and won't arrive until the end of September. They're clear plastic, so the guys can't hide anything in there. And at \$345 a pop, it's a small taste of the prison industrial complex.

The goal of the Prison to College Pipeline (P2CP) is to increase the number of incarcerated and formerly incarcerated people who go to college and succeed there. In a broader sense, the initiative tests a model for the vital role that public universities might play in using higher education to promote successful prisoner reentry and, by extension, generate safer and more robust communities. The initiative addresses a question posed by John Jay College's President, Jeremy Travis, “If over 700,000 people are leaving our prisons, how should the nation's educational institutions be organized to help them make a successful transition to free society?" Elements of the pilot include:

Academic Coursework-Credit-bearing classes taught in the prison by John Jay faculty. 
Workshop Series-Bi-weekly sessions on "Success in College and Life."

Learning Exchanges-Monthly seminars taught by different CUNY professors bring "outside" John Jay students into the prison for college classes with "inside" students.

Reentry Planning - A community partner, the Osborne Association, conducts social service needs assessments and case plans for men. These plans address the range of individual needs: parole appearances, residence upon release, subsistence, treatment, family concerns and compliance with criminal justice conditions.

College Placement-Also in preparation for release another partner, the College Initiative, meets with DOCCS students to help them choose the appropriate CUNY college and apply for financial aid. CI also matches students to mentors.

Film Series-To bolster the intellectual and cultural life of the prison's broader population, the P2CP launched an annual film series, open to all interested men at the prison. Directors accompany their films and engage in a $Q \& A$ after the screening.

-P2CP Program One-Sheet

\section{August 30, 2011}

I nearly cry when I enter the classroom. Miraculously, 14 incarcerated students have materialized. Arthur Kill Correctional Facility, the Staten Island prison we were initially meant to be working in, had been dramatically shut down weeks before our launch. It was Governor Cuomo's doing; he'd vowed to close some of the prisons his father had been responsible for opening back in the 80 s, during the "war on drugs era"-back when prisons made money and provided jobs, as opposed to drained states' economies, as they do today. Never mind that Arthur Kill-despite its unfortunateyet-eerily-appropriate name - was one of New York's only geographically humane prisons, as it's located in New York City and thus accessible to the incarcerated men's families. The NIMBY choir demanded all barbed wire banished to up-north territory, and so it went; Cuomo could look progressive and home-owners feted. We, on the other hand, wept - bereft of a prison to teach in. Until, that is, we moved to Otisville, some 2 hours upstate. I was asked to make a list of my selected students, who, assuming eligibility-physically fit enough to walk the miles-long hike from dorm to programs; no enemies or gang affiliations there-would be transferred to Otisville to become college students. As I frantically made and remade my list, the Dep. morbidly joked that I must feel like Oscar Shindler.

The men were shipped off. One lone student, Stephen, remains at Arthur Kill, and will hopefully make it to Otisville in time to begin class; the Dep. has assured me that "classification and movement is on the case." Getting the men's GEDs and diplomas proves the next tiresome task. No document belonging to an unfree man is easy to put hands on. Somehow, though, the documents had made their way and the bodies had arrived: I have a class.

During orientation, Professor Dreisinger explained that we as a group had earned the right to be here. Her words had an enormous effect on us: We earned the right to be here. Being the very first class put a lot of pressure on us to excel and be ambassadors of the program. The excitement level among my class mates was incredibly high, and starting class in September was the only thing I wanted to do. -Rowland Davis, inside student

\section{September 7, 2011}

First day of class. Dramatic flooding on the highway turns a two-hour drive into three. I'm fingerprinted with heavy-duty ink that demands turpentine for removal. Janet, the volunteer services coordinator, tells me I'm now an official Department of Corrections volunteer, which means she'll get the call immediately if I'm ever arrested. I am accounted for, stamped, photographed, fingerprinted, officialized, TB-tested.

"Civilian pickup at 17," comes the call for my ride to the classroom. In class I set the seats up in a circle. 10 men: Three students already have credits for this course from their previous college-student incarnations, and no Stephen-he still hasn't been cleared for transfer. I envision him as the lone prisoner in a ghost of a yard at Arthur Kill. We go over the syllabus for English 101, which I've themed "Reading and Writing, Race and Identity." They're overwhelmed, they tell me, by all the upcoming assignments. I tell them that's how any student, looking at the semester ahead, is liable to feel.

We delve into the mammoth subject at hand: what's "race"? Jason says he's not "Hispanic" in the way everyone expects him to be. We read an excerpt from Richard Rodriguez's autobiographical polemic Hunger of Memory, in which he talks about tokenism and higher education leaving him in no-man's land: alienated from the Mexican world he grew up in, ever an "Other" in whitebread academic circles. They get it immediately. William asks if I read the rest of the book.

"Yes. Why?"

"Does he have kids?" William persists.

"Why?"

"Does he teach them Spanish?"

"Why do you ask?" I press him. "Does he have to?" "Of course. He's Spanish. That's just what he is," William states. Kenneth mutters something about Rodriguez being a brown Uncle Tom. "He's really a sellout?" I ask. "Is he under obligation to be what he was born into?" The guys grapple with this. I'm surprised: If anyone should be invested in the right to construct yourself, as opposed to letting someone else construct you, it's these guys. But notions of culture and loyalty run deep.

My invented term of the fabulous-teaching day: "Pleasing-the-Provider Syndrome." It's one reason professors rave about teaching in prison. Unlike outside students, who need to be reminded of why they should care about whatever it is we are droning on about in those hallowed halls of academe, incarcerated students drink it in and the whole thing pleases us immensely. Yes, they do so first and foremost because they're hungry for knowledge. But they also aim to please- 
because prison has a way of reducing men to young men longing for something simple: a pat on the back and a "nice work."

Journeys to prison involve long drives through "rolling farmland or forest," during which you are

“immediately aware that you are 'on your own,' far from what you usually know as civilization, relying on your own devices. You feel insignificant and powerless in the face of an imposing structure of masonry and organization." Upon arrival, you pass through "entrance rituals," through which you are "taken into the control of the institution. You be come aware that you enter at the will and pleasure of the institution...entering the prison takes on the ritualistic qualities of what Foucault called a cere mony of power, wherein you are, first, separated from the traditional props and supports of your 'normal' life and, second, wherein those props and supports are replaced by different structures and supports...the ritualized entrance to the prison by you as an employee sets forth the role that you will occupy. The twin feelings of isolation and loss of control." -Werner

\section{September 14, 2011}

I take public transport to prison. Unsure as to whether the Coach Bus service to Middletown, New York, really exists - ever the provincial New Yorker, I'm unsure whether Middletown, New York, even exists-I arrive inordinately early. The bus drivers, mainly of color, milling about in their green uniforms give me whiffs of Otisville. All institutional uniformssanitation workers, postmen, UPS workers - have a way of evoking prison. Are they like prison, though, or is prison like them?

The bus does exist. I fall asleep on it and awake to the smell of green hills and country. I emerge, though, in a setting far less Rockwell-esque. Middletown looks like one of many upstate towns that NYC-money forgot: bombed-out houses, depressingly deserted streets, an economic lifeline that lives behind barbed wire. In these towns crime runs deep; Newburgh, some twenty minutes away, has one of the highest murder rates in the country.

With an hour to kill I eat breakfast at the Coney Island Diner. It's a cliché scene from a bad movie: bigcity girl walks into saloon and all the locals spin right around with glares, knowing she's not from here. I order an egg-white omelet; the waitress asks if I want fries with it. The woman next to me douses her pancakes in syrup and curiously scans the cover of my New Yorker magazine.

I take a taxi from the diner to the prison. As we pull up to the gates, my driver mutters something about it being "very bad." What, I ask?

"Very bad place. All bad. Bad people." I think he's saying "all black people," so I sigh and agree, shaking my head and adding something about the racism of the system.

"Bad, evil people," he keeps muttering, as I realize what he's actually said.
"No, not really," comes my intervention, landing on deaf ears.

In prison, a new guard processes me at 17 . He's justtransferred from Mid-Orange Correctional Facility, also shut down in Cuomo's prison-closing dramatics. As he sunnily stamps my hand, he says he's real glad to still have a job, considering all the shufflings and closings. His colleague, meanwhile, commutes all the way from the city every day — he used to be at Arthur Kill.

In the classroom we talk personal essays. Theron writes about the mostly white, gifted school he went to in Queens. William also went to a private school in the Dominican Republic. The guys show up soapboxready, with pages of notes and particular page numbers to reference. Kenneth and William - the biggest and smallest guys in the class, respectively-go head-tohead about the racial dramatics they're starting to formulate for their personal essays; at issue are tensions between African-Americans and Dominicans. The discussion gets heated. Was choosing to focus on race, given the prison context, a risky idea?

"Civilian pickup at 17," comes the call.

\section{September 21, 2011}

The horses are out in full force today. Otisville is the only prison in New York - and one of the only ones in the country-where Corrections Officers still ride horseback. It's fitting; the place looks like a rambling plantation. A former TB sanatorium, Otisville has all the makings of a summer retreat: rolling green hills, crisp upstate air, picture-perfect vistas - all deemed, by early $20^{\text {th }}$-century doctors, ideal for restoring one's good health.

"Inmate Cowden," I'm told by the educational supervisor, won't make it; he'll have to start next semester.

I show up with their personal essay drafts edited; the prison officials had collected, scanned and emailed them over to me so I could do so. I'm pleased with the process I'd devised and ask the guys if went smoothly on their end. Pause.

"It's aight, professor. But we didn't like how it went down."

"Why?"

"Because we had to give them to-ya know. That's some personal stuff in those essays."

I cringe. I promise them that the COs and counselors didn't read the personal essays - they just scanned them electronically, really — but I'm beating myself up: Unknowingly I'd violated a teacher-student bond.

Our debate about The Color of Water is, as ever, heated. Because it's about race and because it's in prison, all conversation seems intensified, magnified. Kenneth can't stand the book's racially ambiguous protagonist, Ruth McBride Jordan, born Jewish but selfidentified as African-American. He thinks she's a cultural sell-out and should have told her children "what they really were." William disagrees. Kenneth mutters something about William and snitching. Kenneth: What's your name again? Where's that name tag? I cringe again, and try to smooth it out.

"You guys are tripping! It's not that deep. Chill." 
"Don't worry, professor," comes the chorus. "We have thick skin. This is just how we mess with each other."

On the way out I make small talk with Officer R, the $\mathrm{CO}$ on our classroom duty. She's in her early 40s, affable and pretty. She's the mother of a toddler and grew up in this area.

Home, I wash my hands to get the smell of institutional soap off them. Eau de Otisville always seems to linger on my clothes and hair. I read their essays. Kenneth's is all about Dominican discrimination against black people. He writes of being locked up for the same crime his father committed.

\section{October 5, 2011}

Best class yet. We edit essays as a group, painstakingly; everyone is receptive and on point. Except, that is, for Edward, whose essay was one long unpunctuated paragraph devoid of personal narrative. He's ever anxious: to reveal too much, say too much, even look me in the eye. They like the New Yorker profile I'd given them about the one-time car theft, but they love the Junot Diaz story, "Negocios," about an acutely failed man: a Dominican who leaves his family behind, only to start a new family in America. We run out of class time so the discussion will have to wait until next week, but the guys sling opinions as they set off for the hike back to dorms.

"Ramon is my man!" declares Kenneth.

"Nah, he ain't no good!" rebuts Rowland.

"This class is interesting," says William.

I stop by the library to see what might be of use to their upcoming research paper assignment. There is no librarian, thanks to budget cuts. There is a Cornel West title or two, a minuscule African-American sectionand an outsized "fantasy" section.

1844: Eastern Penitentiary in Pennsylvania hires a teacher and opens a library.

1847: New York state permits the hiring of two teachers per prison.

1861: In the Detroit House of Corrections, religious covert Zebulon Brockway launches educational and industrial programs and permits inmates to earn wages.

1870: The National Prison Association calls for universal education in prisons.

1876: Brockway relocates to a correctional facility in Elmira, New York, where he pioneers academic advancements: 28 classrooms, a vocational section for 36 trades, a 600-seat lecture hall, a Sunday lecture series, an inmate newspaper and courses in psychology, political economy and the sciences. Completion of English literature becomes a requirement for parole. The public baulks, dubbing Elmira a "palace prison."

1910: At the International Prison Congress, Zebulon Brockway states that prison is not about punishment "but, instead, education by practice-education of the whole man, his capacity, his habits and tastes, by a rational procedure whose central motive and law of development are found in the industrial economies."

1949: The Correctional Educational Association is born.

1970: 100 years after the American Correctional Association Congress endorses education within prison, sections 136 and 137 of the Corrections Law in the State of New York require the New York State Department of Correctional Services to "provide each inmate with a program of education which seems most likely to further the process of socialization and rehabilitation." 1971: The Attica Rebellion leaves 43 dead. Among the demands of the rebels: more education.

1994: Some 350 college-in-prison programs exist across America-but New York State, for the first time, spends more on prisons than universities.

1994: President Clinton signs an omnibus crime bill making incarcerated students ineligible for financial aid, despite the fact prisoners received less than 1 percent of the total $\$ 6$ billion spent on such aid that year. 1997: Seven college-in-prison programs remain in America.

\section{October 12, 2011}

I drop off my mobile library at the Superintendent's office for clearance: a load of books about the history of racial classifications, for the guys to use in their research papers.

Making my way through security I put on my extrafriendly face. I am ever aware of how I am seen: liberal city-girl do-gooder. Shoes off through the metal detector. Smiles.

"You doing this again next semester?" asks CO with metal wand.

I tell him yes, though we're trying to expand the program and a different professor will start in January. But yep, the program will stick around.

"Good," he says. I'm surprised.

"Why? It's more work for you guys, with us coming and going."

"We want these guys to be busy doing good thingsless trouble for us." I tell him I'm glad he feels that way.

"A lot of these guys are scumbags but there are some good ones," he declares. "And you're college, not GED, so you got the good ones." He asks about money; I explain that we pay the inmates' tuition.

"A lot of people feel like, "why should they get a free ride?" he says, flatly. I tell him I understand where they're coming from.

"But CUNY tuition is very affordable, especially with liberal financial aid," I add, also saying something about incarcerated people not being eligible for that, since 1994 . He seems mildly interested.

I wait on my escort to class. I'm early. The $\mathrm{CO}$ who always arranges my escort-which I don't really need but am required to have-looks up at me, with what I interpret as a scowl, from her Campbell's soup can. I smile at her and try to make small talk about my ride up from the city. She gives me the once-over a few times over.

At the classroom building, Officer R-funny to still not know her first name; prison is last-name territoryis in a good mood. She compliments my jacket. She 
tells me that the library is still closed, for two more weeks. Then a librarian will come in but he'll only be around for two months, for some bureaucratic reason I don't comprehend.

Class begins with a collective moan about the typewriters, which are all but useless to anyone except those comfortable with outdated technology. Kenneth says he has blisters from writing by hand; I jokingly tell him it's only right - education is labor. They hand in their papers. Raheem's is in a plastic sleeve ("I didn't want to mess it up") and Marcus's comes in an Otisville Correctional Facility envelope. Most of them, tellingly, have put their DIN numbers on the right-hand corner, alongside their names.

We delve into Junot Diaz's story. Surprisingly, eversilent Edward volunteers to read his journal entry aloud. It's a pointed critique of Ramon. Raheem agrees: Ramon's a hustler. He hustles everyone-wife, kids, new wife in America. Kenneth jumps in with his journal entry, a defense of Ramon: "I, like Ramon, abandoned my family. I sold drugs, I hustled, I robbed people. But I can correct myself, like he did-in the end Ramon sent for his family. He tried to come correct."

I ask if the rest of the class has any empathy for Ramon. Rasheen: Hell, nah. Kenneth: So how can you expect anyone to have empathy for us? Rasheen: I don't!

William: I knew how this story was going to end after I read five pages. I know a million stories from DR just like this. He uses a Spanish term to describe what Ramon is, a term neither he nor James can translatecall it "good-for-nothing." Ramon is selfish and irresponsible. Rowland: But I get why Ramon didn't write his family back home; it's like us here not writing home-sometimes it's like there's nothing new there, so why should I bother? Me: Why else wouldn't he write home, from a psychological perspective? Class, in unison: Because he's ashamed. Ramon's family is a reminder of his failure. Instead of having to face that, better to simply block it out. Why be around someone who's a reminder of the ways in which you've screwed up, grandly? They nod; they get this. Me: How does the narrator feel about him? James: the story reserves judgment-like James McBride does in his book. Ramon is like Ruth McBride Jordan: how we judge that character is a literary Rorschach test, revealing more about us than them.

As class ends, Robert asks about next semester; I tell him they'll be taking Anthropology 101, and I'll be teaching English 201 next fall. A few say they'll be outta here by then. Me: Good-you'll take it at CUNY. Theron: Yes, I'll be back at 59 street and $10^{\text {th }}$ avenue, like I was 20 years ago.

I always make a point of saying, "When you're home and in CUNY," because I want to program it into their heads. Speak and it shall be so: you will come home, and you will attend college when you do.

I love to write. I truly thought I did a good job, and I did, but Professor Dreisinger gave me a wake-up call. I still had a lot to learn. All the RED marks and the revisions she suggested frustrated me. But I did what needed to be done. -Theron Smith, inside student

\section{October 19, 2011}

Returning papers, their narrative essays, is a cruel task. They want As, but I'm maintaining usual standards and high expectations. The disappointment is palpable, and my assurance that they'll be doing revisions and thus these aren't their final grades alleviates nothing. They wrote rich narratives about their first experiences of race: Marcus on the white man in the living room who turned out to be his grandfather; Anthony on his Puerto Rican best friend, Cocoo; Robert on the Indian Guyanese girl who wouldn't date him because he's black; Theron on being bussed into a better school; James's sage conclusion: "I am neither black nor white. I am not Hispanic nor Latino. I am Boricua, and on a census I will write Boricua on the line that states "other." I will not be identified with the slave titles of Hispanic or Latino, and I will not identify myself with a race that will not recognize me as part of their own."

Things lively up during our discussion of today's readings, which include an essay by Eric Liu about being what he calls a "banana": Asian on the outside, white on the inside. James compares him to Richard Rodriguez, the class's favorite punching bag: Mister Racially Confused. James reads a personal journal entry about how people expect him to be a certain way because he's Puerto Rican. William plays the essentialist again: Liu is "sad" because he's "really" Chinese and can't pretend to be white. I press on: Is he "really" Chinese? Isn't life a tad lame if we're simply born into something, sans identity wiggle room? I point to Liu's list of so-called "white" characteristics. If Liu has those characteristics, isn't he, then, part white? William: there's no such thing as "white culture." Kenneth: it doesn't matter anyway because the world pegs you, and your own version of who you are is beside the point.

The guys are coming alive. William, 25, is the quiet, hyper-observant one who can be counted on to jump in with key questions at the height of the discussion. Theron, 41, is the nodding scholar, liable to drop a name or book title at a fitting moment. Raheem, 26, is the hip-hop jokester, thoughtful and studied, wearer of an expression that toes the line between smile and smirk. Kenneth is an incredible hulk with a sensitive streak. Juan, 35, is the gifted student with the face of a child, calm and kind. Edward, 29: Is he with us? I can never tell. Marcus, 30, is the family man ever eager to come correct. Tony, 33, is ever laughing and likeable. Rowland, 38, is my reliable right arm-knows the ins and outs of how to make things happen when bureaucracy stiffs us. I'm curious to see how they'll interact with the outside students, to be bussed into prison for our first learning exchange later this week.

I am interested in taking such a class because I believe that it would be a great working experience. I believe that everyone should have an equal opportunity and that we would all be able to learn from each other. 
I would be interested because I believe that it can help inmates at a second chance for a career after incarceration.

I would be interested because I believe that it can help inmates at a second chance for a career after incarceration.

Not interested because it is a safety hazard for John Jay students. Although this program may be beneficial to inmates, John Jay students should come first.

I just hope this program doesn't devalue John Jay as an institution. I'm not sure where I stand on allowing inmates to attain a degree with the same name that will appear on my degree.

I don't know how civilized the inmates are. They are put in there for a reason why are we going to go sit with them . . . They aren't meant to be with us. -Student responses to a survey taken in January, 2011, about the possibility of taking a class inside a prison

\section{October 21, 2011}

Driving a cohort of CUNY students upstate is as close as I've come to a class trip in a long, long time. To these hardened city dwellers, a sleepy suburban town like Otisville might as well be Arkansas. They "ooh" and "ahh" at wood-paneled houses on country roads, garnished with American flags.

I guess I did not expect them to be so intellectual. Their use of words when expressing their positions were exceptional. The manner in which they communicated and address the issues during our discussions was well presented. Throughout the discussions I kept asking myself, "How did these guys end up in this place?"... I don't know what they did to be locked up but it would be good for society to help them this time...I cannot explain it but when it was time to leave and I walked out that room, something in me felt very different. There was a mixture of excitement, a newfound understanding, and inspiration. -Patrick Gallimore, outside student, in an email right after the first learning exchange

\section{October 24, 2011}

First day of office hours, prison style. Theron, William and Tony show up in their counselor's office to speak with me by phone, one by one. Hardly ideal circumstances: They don't have privacy. Yet another teaching-in-a-panopticon moment.

They rave about the learning exchange: It made them feel like so-called normal college students; the outside students were smart and friendly; they can't wait for the next one.

\section{October 26, 2011}

They haven't stopped raving about the learning ex- change, so I ask them to write in their journals about it. Their words:

William: The feelings are excitement and happiness. Mentally it removes me from jail, prison or whatever you may want to call it....I was impressed by the students. I can see that they apply themselves and know how to express their ideas. Something I can learn as I struggle to accurately express myself.

Marcus: I wouldn't say that I felt dumb, but I felt kind of strange because I didn't participate as much as I should have.

Kenneth: I need more of that, or should I say the college settings. I've never experienced anything like that before in my life. It was truly remarkable. Never in my life did I believe that college was fun. John Jay did me a big favor in selecting me for this program. The students-wow! Fun to learn with. I can't wait to get out and go to John Jay College.

James: One thing that stuck out to me is the way the other set of students were able to word what was needed to be said.

Tony: I cannot describe my feelings about Friday's class. I've never been in such a setting. The intellect in the room was exuberant. I walked away from this class with an overwhelming thirst for knowledge. While hearing such an exchange of ideas, I realized I've finally made the right decision.

Raheem: It's been a while since I was put in a classroom setting with people I didn't know. So in the beginning of class it felt a little intimidating. I didn't want to say anything stupid, so I held my participation to a minimum. That's the only thing I regretted after class.

I'm struck by the irony: each set of students felt intellectually intimidated by the other. It's not only about intellect-it's about voice and expression. The guys inside have profound anxiety around this issue, probably because they exist in a space of total voicelessness: Life behind bars. I think of William's remark, during our office hours chat, about wanting to express himself better. When it comes to voice, college and prison are ultimately profoundly at odds. The former is about cultivating expression; the latter, suppressing it.

Grammar boot camp produces lots of laughter and camaraderie. I make another attempt to assuage anxieties about final grades; they don't want to hear it. The level of investment here is triple what I'm used to, and I fear backfire: Disappointment can be motivation's greatest foe.

"Can I ask you something?" comes the question from the $\mathrm{CO}$ on my way out.

"Not to sound stupid, but--" he continues. I dread what's coming next; this particular $\mathrm{CO}$ has never exuded much warmth, and I suspect I'm about to endure something along the lines of, "Are you really a professor? How old are you?" Wrong.

"My daughter is in college in Pennsylvania and she is studying to be a teacher. What do you need to be a professor?" We have a nice chat about her options. I think about the fact that our educational presence at Otisville isn't just providing a service to the inmates; prisons can be educational dead zones for all parties. Some irra- 
tional us-versus-them voice within me, though, gets pangs of guilt about being buddy-buddy with COs. Especially following class, after I've bonded with the men in our little educational cocoon.

\section{November 2, 2011}

One of the COs tell me he doesn't like even visiting New York City, even though he grew up in Brooklyn, because there are too many bars on the windows and locks on the doors. He moved from Brooklyn to prison country over 20 years ago.

"I've worked behind bars for over 25 years. Don't want to live behind bars, too," he says. Robert immediately comes to mind; they're both from the same Caribbean island and Brooklyn - and now on very opposite sides of the fence. I ask him if he runs into former inmates when he visits his old neighborhood.

"All the time. I see them in the Caribbean, too-the ones who've been deported."

Class is spent on peer reviews of their research paper outlines. On the way out I enjoy a chat with Officer R about her wanting to go back to school, maybe after she retires in eight years, when her son reaches the double digits. I tell her I'll bring up some John Jay materials for her. She's pleased.

\section{November 9, 2011}

Sick! Have never felt so guilty for missing a class.

I grade papers from my sickbed, though. It takes me on a manic-depressive ride: The good ones prompt bouts of ecstasy, but the grammatically challenged ones make me want to throw up my hands in frustrated disappointment. I notice the same errors again and again - and they're the same ones that plague my nonincarcerated students: sentence fragments, comma splices, subject-verb agreement issues. It's a reminder that what surprises me most about this semester is how few the differences are between these students and my non-incarcerated ones. Ultimately, and between sneezes, I ride a high: They've just written their first college research papers, with limited resources and no experience. And James got an A!

I skim their journals. Rowland's entry on fear sends chills down my spine: "Each officer on either side of me jabbed the ends of their axe handles into my ribs and dared me to come off the wall. What happened next left me in utter shock. I was told by the first CO that I was no longer in the city jail and they play by a different set of rules. 'We will kill you if you get out of hand with our officers and female staff. As far as we are concerned, you and the rest of your monkeys can kill each other." What comment can I possibly write in the margins of that entry?

\section{November 16, 2011}

You're a Jewish prisoner in a concentration camp. A Nazi guard, on his death bed, asks you for forgiveness. What do you do?

This is the premise of our reading for the day, themed around race and forgiveness: Simon Wiesenthal's The Sunflower. Our edition includes Wiesenthal's narrative along with a host of responses to the query he poses, by everyone from religious leaders to academic scholars.

The discussion is surprisingly slow going at first. James makes a nuanced comment about theme of neutrality in the text: When it comes to God, nations, people-you simply can't be neutral. Kenneth picks out a profound passage about God being on leave in the camps. The class nods. I'm floored: the men deeply identify with Simon, the prisoner. Raheem reads from his journal: "I wouldn't have given the Nazi soldier the satisfaction of knowing I forgave him. Walking away from him without a response would have been my only response." Theron: "I would have told Karl that as long as his comrades allow him to breathe, forgiveness is not an option...He was part of a collective ideology that murdered millions...As with slavery, I cannot forgive what was done." James: Forgiveness is about your healing process, not the other person's, but Karl's apology is not sincere. It's criminal thinking-quick and easy.

"Wait, wait, wait," booms Kenneth. Conversational intensity suddenly ramped up forty notches.

"You've committed a crime," says Kenneth to James.

"Yes."

"Do you want your victim to forgive you?"

"My victim is no longer here. But I will be out soon." And, James continues, "I expect that they will have to see me, and it'll be a reminder every time."

"My victim's mother said she forgives me, at my trial," says Theron.

"But still"- - interject—-you just read that you are vehemently against forgiveness."

"Right," says Theron flatly.

Kenneth reads a stunningly sensitive journal entry about the dangers of too much forgiving and too much unforgiving. It's so moving that James declare it changed his mind. Robert reads his entry, arguing that there's no such thing as forgiving but not forgetting, "because do you really forgive if you remember what they've done to you? If you forget then the idea of forgiveness is more real." He reads on: "The moral dilemma Wiesenthal presents is a great reminder to the human spirit. It pushes you to really think about the lives that you have hurt in the course of your life. The victim's family in my case will never-he crossed this out-probably never forgive me. I empathize with them. But I would still ask the age old question, 'Would you ever forgive me?'" Me: Although maybe "forgive-but-don't-forget" means forgetting the anger, not the event? James: But you'll be reminded of that anger every time you think of the event. Raheem, with that ever-ironic smile: Forgiveness is simpleforswearing revenge. That's it. William, quiet but keenly observing until now, pipes in with his journal entry. Ever the eagle-eyed naysayer, he's managed to finds a host of nuances in the text suggesting Karl the Nazi isn't really that bad of a guy. The class pounces on him; he seems pleased with his contrariness. After class, he slides over to me.

"Professor, are you Jewish?" I say no, which is partly true; being born into a religion doesn't mean you are it. 
"I hope I didn't offend you." It would take a lot to offend me, I reassure him.

I'm walked out by a $\mathrm{CO}$ who's new to me. He has rich blue eyes and a baby face. "I've been here for 12 years," he says.

"Really?" I'm genuinely surprised. "You don't look old enough to have worked here 12 years."

"I started at 21," he explains. We climb the hill. "I got straightened out in prison. I got in lots of trouble as a kid and ended up with a GED. My family members work in corrections so it made sense. We all work inside. But now I want something more."

"College?" I ask.

"I can't afford it."

I run down the list of why he can.

"Yeah, I'd like that. I read philosophy books on the job. Joseph Campbell, Aldous Huxley. But there's only so much I can learn on my own, you know?" I tell him I'll bring some information for him next week. I'm starting to feel like the Ambassador of Higher Education.

\section{November 23, 2011}

The vibe is off in the classroom. It's the grades again. We have higher expectations of ourselves than you do, they tell me. We want As. Kenneth scowls at me. Rowland arrives an hour late. Marcus comes in late, too, with an eye that looks sucker punched. I say nothing about it but ten minutes after Marcus arrives, Tony tells him to leave the eye alone-stop playing with it. Marcus says they didn't do anything for him at the infirmary; can I ask the CO to take him back there? I send him off with the blue-eyed CO, who's outside reading Brave New World. Amazing how the bad energy of one student can overpower the good energy of all the others. James, after all, is at his peak - seeing himself as a scholar and thus carrying himself with newfound gravitas.

We're back on Richard Rodriguez, discussing the transcript of an interview he did. The guys think he's "funny." Raheem: He doesn't mean the shit he sayshe just want to piss people off. Is that bad, I ask? Not necessarily, says Raheem. We discuss Rodriguez's claim that he is not a "real minority" because he is not poor. Theron seconds that motion, but Robert points out that it all comes down to definitions: What's a minority? Yes, I say, and what's "real"? We read the section in which Rodriguez claims to be more Chinese than Mexican. They snicker.

"But wait," I press them. "Are we back at, 'You are what you're born into?" No way, says Theron; it's like Ruth McBride Jordan - invent yourself. Juan: It doesn't matter where you happen to be born. Shakira, for instance, is Colombian because of culture, not accident of birth.

"Why doesn't Rodriguez give back to his community instead of running his mouth?" says William. Robert: But what's "his community"? Exactly, I exclaim. And is he obligated to give back? How? William: education. Me: But aren't his books an offering of education?

We have fun with Noel Ignatiev's piece on the aboli- tion of whiteness, in which he states that "treason to whiteness is loyalty to humanity." How can we create a world of so-called reverse Oreos, I ask. How can white people start acting in un-white ways? They fast recognize that this leads us down all sorts of funky paths about what "white" means. Theron reads from his journal: Whiteness "is so deeply ingrained in the consciousness of white people that some think it is just the color that is white and are oblivious of how deep it is interwoven into the psyche of this nation." Tony proposes an example of violating the rules of whiteness: objecting to a publicly uttered racist joke.

"That's not un-white-it's anti-racist," says Raheem. "Is that what he means by 'un-white'?" William insists that it doesn't matter because racism will disappear in 20 years, anyway - it's already disappearing. Class eruption on William again. He turns to me.

"But professor, what do you think will eliminate racism?"

"Nothing," I say. "Maybe education - a big part of why I became a professor."

"Nah," says James. There will always be something to divide us up and discriminate. "It's like this new book, The New Jim Crow. We, the formerly incarcerated-we're the new black." Collective class nod.

\section{December 7, 2011}

I notice a sign that's appeared in the classroom: "Thinking for a change: Our thinking controls our behaviour. By taking charge of our thinking, we can take control of our lives." Prisons are meccas of self-help slogans, most of them concerning control over lives and actions. It's all something of a tease, masking the fact that actually, the men inside have very little control, not now and not when they were on the streets. Given the legacy of institutional racism, true agency of the pick-yourself-up-by-the-bootstraps variety is an illusion. But don't tell that to the slogans.

Second-to-last class is all about revisions. They work individually and meet one-on-one with me. Theron delves right into the typewriter like an old pro. This is life or death for us, he reminds me.

"When you write those comments on our papers, it cuts deep. I was accepted to John Jay 20 years ago and then I took the wrong path. Doing this right is deep." Robert is cool and easy as he slices and dices his written word. Edward tap-taps away with focus. William approaches me with a list of questions about his paper edit.

"I cried, Baz," he declares, staring at me intently. I'm incredulous.

"Over a B? Do you know how many students would do anything to earn a B from me?"

"It's not good enough."

"Stay positive. You're coming home soon. You'll be at John Jay soon."

"So you say."

"Would I sell you a raw deal?" He shrugs; we return to revisions. He seems determined to prove that my suggestions aren't good ones, and tells me he'll follow my advice- - "but only because it'll get me a better 
grade." Edward has a lone question: will I really get these credits on the street? Of course, I tell him. These guys have been sold so many raw deals, they think I couldn't possibly be peddling the real deal.

"Kenneth, you're up." I signal to his scowl.

"No, thanks. I'm good." He looks like a sullen child. What happened to smiling, puffed-chest Kenneth?

"It's not optional," I tell him.

He advances toward me with a heavy gait. What's with the vibe? Kenneth: Nothing - all good. I am just going to hand it in as is. I press him; he blurts out something about being tired of all my criticisms. I don't like how you're trying to change me, change my voice, he says. But it's like a job, I press on. You dress a certain way at work and another way on the street. Is that changing who you are? No, he admits. I sense him softening.

"But you say it's unclear-my writing. I went through the whole spineless book, did all those exercises, and I don't think I can write clearly. I don't. That's it—that's the deal."

You can, I insist; we can go through each sentence with a fine-tooth comb and work through it. But, in a form of protest, he didn't even bring his paper with him today. I'm just a better debater than writer, he insists. So am I, I tell him. But you can be a good writer, toowhatever profession you go for, you need it, and blah blah blah; it's the requisite "writing-well-is-alwaysimportant" speech and it's one big cliché to my ears, but I still deliver it with zest.

"It's painful, those comments," Kenneth sighs.

"I know," I tell him. Writing is pain. Those articles I gave the class, the ones I wrote, had my blood, sweat and tears all over them. But you are talented and it's up to you. Your choice. He nods.

I ponder high expectations and overinvestment. What a curse they can be: With hopes so high, that plummet back to reality has the potential to produce a powerful thud. The men I see revising today aren't the proud, hopeful men they were on the first day of school. Am I killing hope? How can I balance being tough with generating confidence? The educational honeymoon period ended with that first set of grades. I experience this to some degree with all college students, but here it's larger-than-life. For these men, a whole sense of self is wrapped up in that letter. It'd better be an A.

I head out with Officer Blue-Eyes. What were you reading today, I ask.

"Oh, just fun reading."

"Trashy novel?"

"Great Expectations."

\section{December 9, 2011}

Dramatically different learning exchange. Everyone is more comfortable; the outside students are rambunctious as they're cleared, feeling at home in the barbed wire. I have to tell them to pipe down and act professional.

The instructor du jour, Professor Kimora, is a prison regular, involved in teaching programs all over the state and at Rikers. She's part minister, part professor, part counselor, part motivational speaker. In the middle of class, an outside student has a seizure. I have a near panic attack, but Robert and Theron spring into action, holding him up, giving him water and calming him down. It's a stunning irony: Just as they're in there taking a class about the rules of being human and the meaning of "self-actualized," these men are living it. I'm moved to tears as the student returns, shaken but perfectly fine, to class.

Best part of the day: Kenneth strides in bearing a smile and a brilliantly revised essay. I tell him to never, ever let me hear him say he's not a good writer again.

"You serious?" he asks. "I did a good job?"

"Have I ever minced words, Kenneth?" he laughs. Rowland, too, brings me excellent work, and so does Marcus.

But back to the learning exchange. The drama continues as the discussion turns personal.

When I think about arriving at Otisville Correctional Facility I think, quite clearly, of all the ways I had been told to feel. Slightly wary, advised my family. Altruistic, advised my friends. Highly suspicious, advised American society at large. But after passing our proofs of identification up through the driver's side window (the first round of what became a very intense of separation between us and them), some where between waiting to sign in and checking to make sure I left my lip balm in the car, an unexpected emotion began to creep over me: an angry sort of impatience. An acute frustration resulting from the protocols and procedures that took over the morning. All of those tiny, seemingly endless steps we had to move through. And even as these steps became routine over many trips, I began to harbor a mild resentment, recognizing these procedures as control mechanisms, less- than-subtle attempts at division, a perpetual reminder of resident and nonresident status.

It must have been because of this constant reminder of our place in the system that, during class, we did our best to ignore the obvious. We talked around the elephant in the room, carefully avoiding terms that established one another as outsiders or insiders. In our effort to overcompensate for a perceived lack of freedom, or apologize for the imposition of rules, we only managed to increase the divide. The questions we wanted to ask seemed somehow off limits, placed into an imaginary box where no one dared intrude. Except Dr. Kimora during that third learning exchange.

Dr. Kimora refused to step around the obvious as she forced us to look at each other without reserved smiles and polite nods. Dr. Kimora, who in the last session of the first semester began her explanation of the assignment with "for those of you in this room who live here." Dr. Kimora, whose lesson on selfreflection and a discussion of what makes your character allowed us to speak about our differences in our own terms. Acknowledging that while, yes, we 
had all found ourselves in this classroom at Otisville through widely variant circumstances, the traits that made us different as people had little to do with the superficial constraints of the system we were forced to operate in. Only after bringing our most obvious differences to the forefront were we allowed to move past them. From day one I had been told how to feel about people I had yet to meet. The entire structure of the system creates a separation between the insiders and the outsiders. It was truly a grand hurdle to move past this heavily imposed distinction and inter act as students, scholars and nothing more. Dr. Kimora's candidness finally allowed us that luxury. -Lenecia Lewis-Kirkwood, outside student

\section{December 14, 2011}

Last days of class are always bittersweet: Culminations are a joy, but goodbyes aren't. I take the bus to prison. It's Christmas season, so the bus today is making an extra stop at Woodbury Commons, a major shopping outlet not far from the prison. It's thus packed with Visa-bearing people on a mission quite different from mine.

In the classroom, Raheem and Kenneth are chatting about how many classes it's reasonable to take per semester-three? It's a natural segue into our topic for the day: race and the function of higher education. I'd given them excerpts from Paolo Frere's classic Pedagogy of the Oppressed. I break down Frere's talk of "internalization," the idea that one of the tactics of oppression involves a kind of brainwashing: The oppressed are made to believe they deserve to be oppressed because they're fundamentally inferior to their oppressors. The guys get this, viscerally; they know what it is to be told they're no good, again and again. We turn to another article, about whether a student studying to be a state trooper should have to take a literature class. Marcus: You never know when English is gonna be useful. Define "useful," I say. After all, what does a 99-cent storeowner need English 101 for?

"You never know, someone you're trying to sell to might like philosophy," says Raheem. "So I can drop a name or two, or mention Richard Rodriguez, and make a sale. So "useful" means making money, I ask?

"No, also it's good to know on its own. For real," declares Raheem. Theron: There's nothing not worth knowing about. Me: I agree. And that's what I tell my students.

"I'm gonna remember this conversation when I'm out, and having to take a bad class at John Jay," Robert laughs.

Moment of reckoning: sitting one-on-one with them and returning their writing portfolios, with final grades. Rowland is thrilled with his B. I ask Robert what he thinks he got.

"B," he says. "I've always been the student who did OK-I never wanted to be noticed, just enough to get by but not to stand out." I hand him his grade, an A-. "Time to rethink your identity as a student."

Tony expects a $\mathrm{B}-$ but gets a $\mathrm{B}+$. He quietly thanks me for pushing him.
"I think other people believe in me more than I believe in myself," he says. "So thanks for believing in me. Even the journals - I compare old entries to newer ones and I really improved. I felt relaxed, like I can just write."

William is notably terrified. His superb A- pains him, but he accepts it. Theron, to his A-: "Just means I still got a higher ceiling." James's A is a given; I tell him to consider becoming a professor.

"I'm too old," he laughs. I'm rushed and have to make my exit; there is no wiggle time in prison. I leave thinking of all the things I didn't say: How much the semester meant to me, how proud I am, how I've never given so many high grades - so much so that when I submitted them online, I almost felt guilty: More than half the class earned A-'s. Truly earned them.

I take that last-day-of-the-semester ride out of those gates. In the Middletown bus station I'm greeted with a "hey, sweetie" by a man who resembles the rocker Kid Rock, with fewer teeth. A woman with a hefty smokervoice buzzes in my ear. She's on her way to Monticello, and she's reminiscing about the days when Middletown was called Middletown for a reason: There was real industry upstate, and things were bustling. "Things ain't what they used to be," she says with a sigh. I reveal what I'm doing up there, explaining who my students are.

"You call them students. They're inmates," she says, puffing on her cigarette.

"No, they're students."

The bus ride home is surreal. It's storming so it takes almost three hours, but I don't mind because it allows me to unpack this final day. I miss my students. I worry about them being OK for the next six weeks, during winter break; I assure them that the counselor and the Dep. can reach me if anything happens. I have flashes of their expressions as they received their grades - the letter ultimately aimed at replacing their Scarlet-A DIN numbers. There is no effort nobler than that of a person who has erred gravely but labors, steadily, to come correct. Being part of that divine laboring is what motivated me to start this program, and stay with it.

NB: Some names have been changed for the purposes of privacy

\section{References}

Bazos, A., \& Hausman, J. (2004). Correctional Education as a Crime Control Program. UCLA School of Public Policy and Social Research.

Fine, M., Torre, M.E., Boudin, K., Bowen, I., Clark, J., Hylton, D., et al. (2001). Changing Minds: The Impact of College in a Maximum-Security Prison. New York: The Graduate Center of the City University of New York.

Fine, M., \& Torre, M. E. (2005). Bar none: Extending affirmative action to higher education in prison. Journal of Social Issues, 61(3), 569-594.

Steurer, S., Linton, J., Nally, J., \& Lockwood, S. (2010). The top-nine reasons to increase correctional education programs. Corrections Today.

Werner, D. R. (1990). Correctional Education: Theory 
and Practice. Danville, IL: Interstate Publishers.

Western, B., Schiraldi, V., \& Ziedenberg, J. (2003).
Education and Incarceration. Washington, DC: Justice Policy Institute.

Baz Dreisinger is a Professor of English at John Jay College of Criminal Justice, City University of New York, where she teaches literature, film and cultural studies courses about intersections of race, crime and culture. At John Jay College, Dr. Dreisinger is the founder and Academic Director of the Prison-to-College Pipeline program, which offers college courses and reentry planning to incarcerated men at Otisville Correctional Facility in upstate New York. 